\title{
Citizen Science and the Neoliberal Transformation of Science - an Ambivalent Relationship
}

\author{
Katrin Vohland*, Maike Weißpflug* and Lisa Pettibone ${ }^{\dagger}$
}

The neoliberal turn in science has led to the economisation of knowledge, economic criteria for evaluating research, and a retreat of the state from governance of the scientific system. These steps have important ramifications for citizen science. On one hand, citizen science may add to the neoliberalization of science by filling gaps in "traditional science," such as providing free environmental data or delivering public goods such as education or environmental knowledge. On the other hand, citizen science may provide a way to buck the trend of neoliberalization, by promoting new forms of societal cooperation and mutual learning that may lead to more social cohesion and sustainability, as well as safeguard a non-economized sphere. In this way, citizen science is ambivalent: It can either strengthen or challenge neoliberalization of science. This article describes this idea in more detail and presents practical suggestions for how to manage them, ranging from openly curated data over different types of feedback systems to the development of mutual learning spaces.

Keywords: citizen science; neoliberalism; participatory research; biodiversity monitoring; health

\section{Introduction}

Citizen science, a diverse approach to scientific research that comprises a variety of actors and practices (Kullenberg and Kasperowski 2016, Eitzel et al. 2017) is growing worldwide (Göbel et al. 2016, Storksdieck et al. 2016). It ranges across various types and intensities of participation (Haklay 2013), offers a variety of topical areas and activities for contribution, and involves both citizens and professional researchers in numerous possible constellations.

Most visible and well-researched is the contribution of citizen science to nature conservation. Citizens not only contribute data, but also help to implement effective conservation measures through mutual learning (McKinley et al. 2017; Turrini et al. 2018). The research benefits of citizen science are also clear in the natural sciences, e.g., astronomy (Marshal et al. 2015) or taxonomy (Sforzi et al. 2018), as well as the (digital) humanities (Carletti et al. 2013), including history, art, and archaeology (Oswald and Smolarski 2016). Data from citizen scientists support the development, for instance, of early warning systems in the area of fluvial inundations (See 2019) or public health (Den Broeder 2016). In countless scientific disciplines, collaborations between citizens and scientists have led to the collection of massive amounts of data, discovery of new species and stars, better communication between

\footnotetext{
* Museum für Naturkunde Berlin, Leibniz-Institute for Evolution and Biodiversity Research (MfN), DE

Berlin Social Science Center (WZB), DE

Corresponding author: Katrin Vohland (katrin.vohland@mfn.berlin)
}

scientists and the communities they serve, and action to protect the flora and fauna under study. These benefits have led to the growing importance of citizen science in science and policy (Hecker et al. 2018).

At the same time, some have begun to express uneasiness with citizen science. One concern in particular is that citizen science paves the way for neoliberalism in science, by allowing the instrumentalization of citizens for economic reasons. Eitzel et al. (2017; p. 10), citing (Brown 2015), express the concern that "citizen science in its contributory forms does have the potential to become a neoliberal tool, divesting the state of responsibility for important societal functions and delegating it to individuals." Mirowski (2017) states that "it's not a coincidence that citizen science lowers the cost of research that requires lots of routinised labour." And in fact, cost-effectiveness is one key argument used to support citizen science (e.g., Birkin and Goulson 2015; Simoniello et al. 2019).

In this essay we reflect on the current debate on citizen science and neoliberalism, and the ambiguity of citizen science, which can serve as both civic empowerment and cheap research labor. Because citizen science can either support or challenge neoliberal trends in science, we see it as "ambivalent": More citizen science does not in itself aid or hinder the neoliberalization of science. We use a systems theory analysis of the relation between science, civil society, and the economy in order to make the underlying processes and actors, as well as the changing role of science, more visible (Dickel and Franzen 2015), following theoretical work done by Rebecca Lave, Wendy Brown, and Philip Mirowski. Finally, we develop some suggestions 
for the increasingly institutionalized citizen science movement for how to avoid instrumentalization by the state or companies, ensure fair interactions with participants, and keep a space free of the economization of life.

\section{Citizen Science - Between Science and Civil Society}

As interest has grown in citizen science and the movement has become more professionalized, various actors and groups have sought to define it. What is clear from the practice of citizen science, however, is its diversity: Current efforts range from the individual to the institutional level and from short-term projects to lifelong interests; are initiated by laypeople, civil society groups, scientific institutions, or public administrators (among many more); and involve "science" and "society" in a variety of ways (Pettibone et al. 2017). This makes it difficult, and likely counterproductive, to speak of citizen science as a single or coherent practice, because it includes practices with different actors, missions, and values. To understand the role of citizen science in a society increasingly governed by what one may call the neoliberal paradigm (Harvey 2005, Crouch 2014), we have chosen a systems analysis perspective. This sociological approach sees functional differentiation as the basis of modern society. In this view, about a dozen subsystems have evolved to take over different social functions, such as the economy, politics, religion, art, science, and sports. Each subsystem is constituted by its own guiding value or code, which orients all actions within it. In the subsystem of science, for example, the guiding value is the search for truth; in the subsystem of politics, the value is the allocation of power. Civil society is seen as a sphere between market and state, where activities are done on a voluntary basis (Pagoulatos and Kastritis 2013). It contributes to the problem-solving discourse on questions of general interest (Habermas 1992; p. 443-444).

It is not immediately clear where to locate citizen science in the social system. It seems to be a hybrid object, belonging to two worlds - the scientific system and civil society. On one hand, the definitions of citizen science, e.g., the "10 principles of citizen science" developed by the European Citizen Science Association (ECSA), clearly express that the central value of citizen science is its contribution to scientific truth-finding: Citizen science projects "involve citizens in scientific endeavor that generates new knowledge and understanding" (Principle 1) and "have a genuine science outcome" (Principle 2; Robinson et al. 2018; p. 29). On the other hand, it is clear that citizens' activities within such projects are voluntary and belong in the context of civic engagement. The 10 principles state that the civic side of citizen science adds a value in terms of "greater public engagement and democratisation of science" (Robinson et al. 2018; p. 29) that discerns citizen science from other research practices.

\section{What is Neoliberalism?}

Neoliberalism is a political ideology that places the freedom of the individual at its core, and prefers market-based solutions over government interventions for their cost efficiency, effectiveness, and tendency to foster individual freedoms (Crouch 2014). Indeed, the role of the state under neoliberalism is reduced to protecting the value of money and private property (Harvey, 2005). Grown to prominence as an alternative to socialism, neoliberalism has become the political mainstream in Western politics, beginning in classically "conservative" parties and becoming accepted in previously social democratic political parties, such as among the Democrats in the United States, Labour in the UK, the Social Democrats in Germany, and even Communist leaders in contemporary China (Crouch 2014, Harvey 2005, Stedman Jones 2012). Neoliberalism encourages the privatization of public goods (e.g., public utilities and health care), market-based replacement of state-provided services (e.g., through private contracts and public-private partnerships), and an increasing financialization of the economy and growing corporate power (Tyfeld et al. 2017). In short, the term "neoliberalism" stands for economization of everyday life and a move from concern for the common good to concern for the individual citizen, shaping individuals' rational and ethical frameworks (Brown 2015). Jürgen Habermas has described what we call "neoliberal transformation" as a pathological development of modern societies that arises from money (or power) "colonizing the lifeworld," "displacing communicative forms of solidarity," and inhibiting the reproduction of the lifeworld and other subsystems, e.g., when universities become governed by market strategies (Bohman and Rehg 2017).

Critics of neoliberalism have pointed out several negative attributes. First, the focus on economic efficiency can obscure or harm other values, such as workers' rights, equity, or ethical considerations. In addition, the imagined cost savings from moving public service provision to the private sector may not even be realized, as market actors come with a profit motive (Andrews and Entwistle 2015, Birch and Siemiatycki 2015). Second, neoliberalism leads to commodification, a move of previously non-monetary goods and services into the market, for example in private provision of cleaning services and childcare. This also leads to an economization of human life, which overvalues paid work and undervalues non-economic activities. Third, neoliberalization exacerbates social inequality and increases the power and wealth of large corporations and the capitalist class (Harvey 2005). Harvey (2005) argues that neoliberalism's largest success has been in redistributing wealth, primarily through dispossession, to the world's wealthiest at the expense of the poor. Finally, private service provision and an emphasis on markets leads to a democratic deficit, as decisions are moved from the (democratic) state to markets, whose interests lie more in willingness to pay than in equitable distribution (Crouch 2014, Harvey 2005). Indeed, neoliberal theorists have lodged numerous critiques of democracy, in particular linked to skepticism of a strong state and its negative effects on individual choice (Biebricher 2015).

Neoliberalism is primarily a political-economic ideology, which values individual freedoms above all else, and sees private markets as the best way to guarantee those freedoms. Neoliberalism seeks to reduce the role of society and the state, but what does it mean for science? 


\section{Neoliberalism and Science}

As science became professionalized in the 19th and 20th centuries, the role of the state increased. Governments began to support scientific endeavors by redistributing tax income to research institutions and universities (Redner 1987). In this way, taxes play a guiding role in societies by directing a community's wealth to commonly agreedupon goals. By funding education and scientific research, the state also democratized the production of scientific knowledge. Considering that research in the 18th century was mainly an activity of the wealthy, public funding has contributed to broadening the number and percentage of people who can participate in science. Public funding also gives state institutions a larger role in shaping the scientific agenda by deciding what research to fund. Modern science has become a societal subsystem with its own rules of appreciation and governance, consisting of universities, professors, and research infrastructure. Science relies on monetary resources to fund its activities, so it competes with other societal subsystems for those resources.

However, state support of science is declining, and in many cases is being replaced by market forces (Tyfield et al. 2017). Public funding of research in universities and other institutions is declining (Eurostat 2018), but the amount of private funding has increased in the U.S. (e.g., McCluskey, 2017), and remained stable for the past decade in Europe, constituting "more than half (55.3\%) of the total expenditure within the EU-28 in 2015" (Eurostat 2018). The source of funding impacts research by guiding topics and priorities; one study showed that professors publish less quality research after they got funding from industry (Hottenrott and Thorwarth 2011). Under the neoliberal paradigm, not only is research funding privatized, but the value or logic of the scientific system takes on the logic of the marketplace. What was formerly a public good is now valued "in terms of capital investment and appreciation, including and especially humans themselves" (Brown 2015; p. 176).

Lave (2017) identified five characteristics of neoliberal knowledge production: 1) the reduction of public money for higher education and research, 2) the separation of teaching and research, 3) the outsourcing of peer-review processes, 4) a shift from curiosity-driven research to applied research, and 5) the protection of intellectual property. The last two trends are particularly important with regard to citizen science. The conflict between curiosity-driven research and applied research in citizen science is termed the "tyranny of relevance" (Lave 2017; p. 22). In addition, it is unclear whether citizens should gain public money for their scientific contributions, as well as who owns the data and insights, especially when we talk about crowdsourcing processes. In the next section we explore these issues in more detail.

\section{Key Conflicts for Citizen Science Relevance}

A key ambivalence with regard to neoliberal tendencies is what Lave calls the "tyranny of relevance." Scientists are increasingly trying to highlight the relevance of science for society, and citizen science appears to be under even greater pressure to prove such value. Authors such as Wildschut (2016) and Irwin (1995) see citizen science as essential to closing the gap between society, science, and politics. Citizen science is seen as producing relevant knowledge, but also as building connections between disparate institutions. This illustrates the high expectations for citizen science.

Sometimes corollary benefits of citizen science, such as scientific literacy, seem even more important than the scientific questions themselves. In this respect citizen science becomes an "instrument" to reach political targets. For instance, the European Commission (EC) wants to explore how "citizen science can act as a catalyst to develop scientific skills and competences, act as a tool for informal and formal science education of young people and adults, counter perceived anti-intellectual attitudes in society, raise the scientific literacy of European citizens, and promote social inclusion and employability" (EC 2017; p. 34). When it comes to the evaluation of those projects, data are evaluated "concerning the societal, democratic and economic costs and benefits of citizen science;" consortia are expected to contribute to one or more of the indicators for Responsible Research and Management (MoRRI indicators; for instance for public engagement; (EC 2015) and to the UN's Sustainable Development Goals (SDGs) (EC 2017; p. 37). How many "normal" research projects have to prove that they contribute to "one or more" MoRRI indicators and the SDGs? Citizen science is thus expected by funding agencies to operate not only between civil society and science, but also in the subsystems of politics, public administration, education, and more. It could even be argued that government actors expect citizen science to play a role formerly inhabited by public agencies.

At the same time, these outsize expectations have led to acknowledgment of citizen science at high policy levels, and offer space for positive change, such as in sustainable development. This ambivalence is described by Ottinger (2017) as a contradiction between social movement-driven citizen science and scientific authority-driven citizen science - the latter closely linked with institutions. While this may increase the legitimacy of citizen science data, e.g., when trying to convince Environmental Protection Agencies (EPAs) on biodiversity issues, it also could lead to a missed opportunity for citizen scientists to explicitly challenge scientific standards or indicators, and thus spur governance changes (Ottinger 2017; p. 360), as for example by the Bucket Brigade's collection of peak rather than mean data on air pollution (Ottinger 2010).

\section{Citizen Science - A Free Lunch for the State?}

This discourse about unpaid work in citizen science is important, as volunteer work is at the heart of this approach. Lave (2017) observed that the environmental sciences are particularly susceptible to neoliberal mechanisms of knowledge appropriation, because topics such as climate change or biodiversity loss are less driven by curiosity or "scientific breakthroughs" than the "sense of crisis" where criteria of (also economic) relevance prevail. A research study on the perspective of scientists in 
the project OPAL (Open Air Laboratories) confirms this theoretical consideration: The scientists in charge of the project report that citizens contribute only small packages of information or data, the simpler the better, which do not lead "to revolutionary results" or "eureka moments" (Riesch and Potter 2014, p. 6). The authors state that the "real remuneration for professional scientists [...] is [...] their pay" (p. 11), and also address other critical issues such as the potential outsourcing of scientific jobs to citizen scientists and the competition between professional and citizen scientists (Riesch and Potter 2014). Here, citizen scientists are useful when they deliver data; more than this and they become a potential threat to the livelihood of professional scientists.

As citizen science has this particularly strong tradition in the environmental sciences, especially in biodiversity research (Pettibone et al. 2017), Lave (2017) worries that citizens' provision of free data to environmental agencies indicates a "new wave of appropriation of labor and knowledge" (p. 28). One obvious example is biodiversity research, especially biodiversity monitoring and reporting, in which citizens contribute to national biodiversity monitoring (Chandler et al. 2017). For instance, in Germany, citizens are key contributors enabling Germany to fulfil its reporting duties as a member of the Convention of Biodiversity (CBD) (BMU and BfN 2011). Volunteers identify new species, develop maps, and spot endangered species (for instance, species identified as endangered on so-called Red Lists). In Great Britain, volunteers support the management of invasive species (Pages et al. 2019). Others map invasive species (Crall et al. 2008, Gallo and Waitt 2011), or enter observations of air or water pollution into apps (Moorthy et al. 2018, Palacin-Silva et al. 2016).

How can it be a problem for citizens to care for nature? One concern is that unpaid voluntary work occurs typically with little appreciation and acknowledgement. This retreat by the state is also found in the related area of urban gardening (Rosol 2011). Rosol (2011) showed that a shortage of public money for public green spaces over the last decades led to local government calls for public support (in Berlin, Germany) to care for these spaces. But citizens do not pick up a trowel to save the city money. Instead, they do so because they enjoy gardening, are looking for social contacts, or want safe places for their children.

In some other projects, volunteers are paid for their scientific work, or at least receive some compensation, such as travel expenses, snacks, or scientific resources. Strategic papers such as the Citizen Science Strategy Germany 2020 recommend supporting communication and organization of citizen science activities with professional positions, and offering education, access to information, or other means of (non-monetary) acknowledgement to citizen scientists (Bonn et al. 2016).

There are intrinsic conflicts in this approach: The state tends to outsource its duties, especially in the area of biodiversity monitoring, yet the intrinsic motivation of many citizens is to care for nature, to be outdoors, and to do something they perceive as enjoyable and meaningful. From the standpoint of the state, citizen scientists are a (cheap) means to collect the data and information necessary to fulfill state duties, which are normally expressed in national law following international conventions. The state instrumentalizes their motivation in order to save money, because human labor is necessary to fulfill the duties of the state. As stated above, the majority of biodiversity data come from citizens, not from paid agencies or scientific institutions. Public funding of scientific projects incurs the expectation of an economic impact. This was clearly expressed in the Horizon 2020 funding scheme of the European Union, which advocates investments in citizen science projects because research is "seen as a means to drive economic growth and create jobs" (EC 2019). From the standpoint of citizens, however, the appeal of citizen science as a volunteer project, as with urban gardening or any use of one's time outside the market, is necessarily intrinsic. As long as there are enough interested volunteers to collect scientific data necessary for policymaking in areas like biodiversity, or the data collected can be used by policymakers, the situation could be considered win-win. Problems may arise, however, when policymakers ask volunteers to collect data with certain requirements on what information should be gathered or when. In other words, as long as the state is not paying, it cannot direct the work. At the same time, this trend approaches neoliberalism when the state decides not to fund legally required research for cost-saving research, using the argument that citizen science can do so for free.

\section{Public Work and Private Goods?}

Another problematic area is the commercial use of freely provided data and information (Michelucci and Dickinson 2016). The health sector in particular profits from data provided directly by citizens (Afshinnekoo et al. 2016). For instance, citizen scientists provide gut content for science's sake (Del Savio et al. 2016), provide data on their daily activities (Boulos et al. 2014), or formulate research questions with physicians and health researchers that help to provide more directed therapies (NYU Tandon School of Engineering 2017). However, it is not always clear who profits most from the data collection: The collector, some patients, or the pharmaceutical industry? If these health data are seen more as an asset to be remunerated and part of data self-governance, and less as the result of cheap labor, citizen science data can be a means to empower citizens and support democratic data governance (Evans 2016).

The Open Science Movement suggests open accessibility of data and information. But while larger data aggregators such as Google may profit commercially, the provision of data as "scientific commons" is not necessarily financially supported. Other tensions occur, for instance, with the new EU General Data Protection Regulation (GDPR) using the data of citizen scientists; on one hand a "re-use culture" - which is also part of the FAIR criteria (Findable, Accessible, Interoperable, Reusable, c.f. Wilkinson et al. 2016) - is supported, while on the other hand, according to GDPR the purpose of collecting the data has to be defined in advance (Suman and Pierce 2018). In addition, citizen science is not always hypothesis-driven, but in some 
respects constitutes more exploratory research, where at least some data are collected without a specific purpose. When new research questions arise, the use of previously collected data for these new questions can become difficult given the requirements of the GDPR to indicate the intended use of the data in advance. In addition, international cooperative research (i.e., also conducted outside the EU), may conflict with the GDPR (Quinn 2018).

\section{A Compass for the Citizen Science Community to Navigate Around Neoliberal Cliffs}

Citizen science, located between scientific and societal subsystems of society, is also subject to neoliberal mechanisms - in all their ambivalence. To avoid instrumentalization by the state or companies, to ensure fair interactions with participants, and to keep a space free of the economization of life, we offer recommendations that begin with the call to be self-reflective, and to develop an international ethics of citizen science. For this, the citizen science community must analyse its impact, normative foundation, and practices. And in fact, there is significant potential for self-reflection in the community. For instance, in various projects and initiatives networked in the European COST (Cooperation in Science and Technology) Action CA15212 (Citizen Science to promote creativity, scientific literacy, and innovation throughout Europe), scientists, initiators of citizen science projects, and others reflect on citizen science's potential for change in the relationship between science and other social subsystems: Does citizen science empower disadvantaged groups, and under what conditions? What do citizens gain from participation? Are their interests and goals met by the project? How can they grow personally? Do they learn something or are they being exploited? Where is the boundary between developing research topics, research agendas, and influencing the allocation of research funds, which is a science policy issue? Large parts of the community also meet at national and international conferences and forums to discuss these issues (albeit seldom with the citizen scientists themselves). There are no established structures for a largerscale exchange for citizens, some participants may prefer to spend their free time in their projects and not at events addressing more abstract strategic and political issues, and resources for traveling are often not provided by the projects. Meaningful inclusion of citizens' goals and interests at such events and discourses requires thoughtful, creative work from the scientific community to synthesize citizens' perspectives from the project level, to conduct research that asks citizens their motivations and goals for participation, or even to develop new roles such as citizen scientist advocates to speak for this essential - but often silent - group.

Many actors find themselves together in national or even global networks (Storksdieck et al. 2016). Its members reflect on critical issues and exchange good practices which, increasingly, unite common goals and values. The European Citizen Science Association (ECSA), an association with more than 200 individual and institutional members from Europe and beyond, developed the above-mentioned 10 principles of good practice in Citizen
Science (Robinson et al. 2018), which have been translated into about 30 languages and are referred to by key stakeholders (e.g., LERU 2016; p. 8). Good practice means addressing a scientific question while embracing a fair, acknowledging, and transparent cooperation between different actors, typically citizens and members of scientific institutions. There must be a benefit for citizens, which may be understood differently in different groups. It is critical that benefits fit the interests of participants, not just scientists or funders. In addition, there should be an informative duty to give participants feedback regarding what happens with the data. Means of communication can be newsletters, as practiced by Biodiversity4All in Portugal (Tiago et al. 2017), or annual meetings with the open-access publication of the combined outcomes, as practiced by the Austrian Citizen Science Network (Heigl et al. 2018). Some projects also provide explicit learning opportunities and develop teaching materials, such as the butterfly monitoring project in Germany (Kühn et al. 2014). Personal growth and access to new social communities are appreciated outcomes for participants. ECSA, together with many other partners, is developing the platform EU-Citizen. Science, which will provide these kinds of resources, guidelines, and best practice examples. Another ethical issue is naming of citizen scientists in publications; citizen scientists are often invisible, despite their enormous contributions to science (Cooper et al. 2014). A growing convention in astronomy, for instance, names citizen scientists in scientific publications (Henden 2011).

Monetary acknowledgement also may be discussed. In astronomy, there is a suggestion to include new instruments needed by citizen scientists in funding bids (Henden 2011). The German Green Book for Citizen Science, which outlines a strategy to strengthen citizen science in Germany, suggests broadening eligibility criteria to allow scientific actors beyond scientific institutions to apply for research funds (Bonn et al. 2016). Paying citizens directly for their contributions is an additional option, which changes the relationship between the actors and transforms citizen scientists into employees. Such a solution could be fair, but falls within the neoliberal paradigm by economizing leisure time and is perhaps the most visible expression of intrinsic ambivalences.

Another important aspect of fairness is the accessibility of data. As mentioned above, the citizen science community commits itself to the FAIR use of data - whereby "accessible" means not only physical access to primary data, but also to meta-data and tools for visualization and interpretation. In addition, interests of project initiators, use of data, and cognitive results have to be made transparent.

Last but not least, citizen science - with ECSA as one mouthpiece - links itself to the leading concept of research in the EU, Responsible Research and Innovation (RRI) in the sense that "citizen science can improve social inclusion in a wider scientific community, engage citizens in decisions related to research and innovation, and promote scientific literacy" (Cooper et al. 2016). This also means strengthening civil society as an arena of non-commercial, free community, and as a space for people "not just to act, but to act in concert" (Arendt 1970; p. 44). Despite 
the valuable benefits of citizen science for society, project initiators (either from scientific institutions or from civil society or other sectors) should consider the epistemic implications of citizens contributing to science. By concentrating on and fostering the intrinsic values of both societal spheres that citizen science belongs to - science and civil society - it may even become a stronghold for these values: Curiosity-driven search for truth, civic dialogue, and unimpeded communication.

\section{Conclusion}

From a purely normative perspective, citizen science is driven by scientific questions and curiosity, contributes new knowledge, and aims to provide benefits for contributors and added value for society as a whole. The international citizen science principles of best practice (c.f. Robinson et al. 2018) espouse values different from neoliberalism, which turns public goods into market values and replaces state duties with individual responsibilities. However, observing current citizen science practices, a certain vigilance against instrumentalisation by economic interests or the displacement of state duties shifted to citizens-in other words, a neoliberalization of citizen science-is entirely appropriate. As described, in some cases the commitment of volunteer researchers/citizen scientists is being exploited to save costs, increase legitimacy, or pass on state responsibilities - e.g., for sustainable development or biodiversity monitoring - to citizens. But the picture is not strictly black and white. Citizen science offers new pathways of cooperation and mutual learning between lay and professional actors, and between citizens, scientists, politicians, and the private sector, and it opens new ways for doing research. Citizen science is linked/dedicated to Responsible Research and Innovation (RRI). With its inclusion of new actors in scientific research, citizen science brings together societal subsystems in new ways, and offers an alternative model to the increasing market orientation of research. Citizen science does not per se pave the way for an increasingly neoliberal science; it can in fact mitigate some of the neoliberal tendencies. But its practice and framing by different actors and interest groups must be monitored and reflected upon carefully.

\section{Acknowledgements}

We would like to thank the members of our department "Wissenschaft in der Gesellschaft" and especially Claudia Göbel for their constructive comments on the general issue and concrete paper as well as anonymous referees for their engaged commentary. The work is developed as part of the work done within the COST Action CA 15212.

\section{Competing Interests}

The authors have no competing interests to declare.

\section{References}

Afshinnekoo, E, Ahsanuddin, S and Mason, CE. 2016. Globalizing and crowdsourcing biomedical research. British Medical Bulletin, 120(1): 27-33. DOI: https:// doi.org/10.1093/bmb/ldw044
Andrews, R and Entwistle, T. 2015. Public-private partnerships, management capacity and public service efficiency. Policy and Politics, 43(2): 273-290. DOI: https://doi.org/10.1332/0305573 14 X13917703359707

Arendt, H. 1970. On violence. New York: Harcourt, Brace \& World, 1-106.

Biebricher, T. 2015. Neoliberalism and Democracy. Constellations, 22(2): 255-266. DOI: https://doi. org/10.1111/1467-8675.12157

Birch, K and Siemiatycki, M. 2015. Neoliberalism and the Geographies of Marketization: The Entangling of State and Markets. Progress in Human Geography, 40: 2. DOI: https://doi.org/10.1177/0309132515570512

Birkin, L and Goulson, D. 2015. Using citizen science to monitor pollination services. Ecological Entomology, 40: 3-11. DOI: https://doi.org/10.1111/een.12227S

Bohman, J and Rehg, W. 2017. "Jürgen Habermas", The Stanford Encyclopedia of Philosophy (Fall 2017 Edition). Available at: https://plato.stanford.edu/archives/ fall2017/entries/habermas/ Accessed: 2.2.2019.

Bonn, A, Richter, A, Vohland, K, Pettibone, L, Brandt, M, Feldmann, R, Goebel, C, Grefe, C, Hecker, S, Hennen, L, Hofer, H, Kiefer, S, Klotz, S, Kluttig, T, Krause, J, Küsel, K, Liedtke, C, Mahla, A, Neumeier, V, Premke-Kraus, M, Rillig, MC, Röller, O, Schäffler, L, Schmalzbauer, B, Schneidewind, U, Schumann, A, Settele, J, Tochtermann, K, Tockner, K, Vogel, J, Volkmann, W, von Unger, H, Walter, D, Weisskopf, M, Wirth, C, Witt, T, Wolst, D and Ziegler, D. 2016. Grünbuch Citizen Science Strategie 2020 für Deutschland. Helmholtz-Zentrum für Umweltforschung (UFZ), Deutsches Zentrum für integrative Biodiversitätsforschung (iDiv) Halle-Jena-Leipzig, Leipzig, Museum für Naturkunde Berlin, Leibniz-Institut für Evolutions- und Biodiversitätsforschung (MfN), Berlin-Brandenburgisches Institut für Biodiversitätsforschung (BBIB), Berlin.

Boulos, MNK, Brewer, AC, Karimkhani, C, Buller, DB and Dellavalle, RP. 2014. Mobile medical and health apps: state of the art, concerns, regulatory control and certification. Online J Public Health Inform, 5(3): 229. DOI: https://doi.org/10.5210/ojphi.v5i3.4814

Brown, W. 2015. Undoing the demos: Neoliberalism s stealth revolution. MIT Press.

Bundesministerium für Umwelt, Naturschutz und Reaktorsicherheit (BMU), Bundesamt für Naturschutz (BfN). 2011. Nationale Strategie zur Biologischen Vielfalt. Dialogforum Ehrenamt. Available at: https://biologischevielfalt.bfn.de/fileadmin/NBS/ documents/Dialogforen/DF_Ehrenamt/Dokumentation_DF_Ehrenamt_Feb_2011_barrierefrei.pdf.

Carletti, L, McAuley, D, Price, D, Giannachi, G and Benford, S. 2013. Digital Humanities and Crowdsourcing: An Exploration. Museums and the Web.

Chandler, M, See, L, Copas, K, Bonde, AMZ, López, BC, Danielsen, F, Legind, JK, Masinde, S, Miller-Rushing, AJ, Newman, G, Rosemartin, A and Turak, E. 2017. Contribution of citizen science towards international biodiversity monitoring. Biological Conservation, 
213: 280-294. DOI: https://doi.org/10.1016/j.biocon.2016.09.004

Cooper, C, Serrano, F and Göbel, C. 2016. How "Responsible" is the Citizen Science? Available at: https://ecsa.citizen-science.net/blog/how-responsible-citizen-science.

Cooper, CB, Shirk, J and Zuckerberg, B. 2014. The Invisible Prevalence of Citizen Science in Global Research: Migratory Birds and Climate Change. PLOS ONE, 9: e106508. DOI: https://doi.org/10.1371/journal. pone.0106508

Crall, A, Newman, G, Jarnevich, C, Stohlgren, T, Waller, D and Graham, J. 2008. Improving and integrating data on invasive species collected by citizen scientists. Biological Invasions, 12(10): 3419-3428. DOI: https://doi.org/10.1007/s10530010-9740-9

Crouch, C. 2014. Putting Neoliberalism in its Place. The Political Quarterly, 85(2): 114-121. DOI: https://doi. org/10.1111/1467-923X.12077

Del Savio, L, Prainsack, B and Buyx, A. 2016. Crowdsourcing the Human Gut. Is crowdsourcing also citizen science? JCOM, 15(03): A03 (1-16). DOI: https://doi. org/10.22323/2.15030203

Den Broeder, L, Devilee, J, Oers, HV, Schuit, AJ and Wagemakers, A. 2016. Citizen Science for public health. Health Promotion International, 1-10. DOI: https://doi.org/10.1093/heapro/daw086

Dickel, S and Franzen, M. 2015. Digitale Inklusion: Zur sozialen Öffnung des Wissenschaftssystems (Digital Inclusion: The Social Implications of Open Science). Zeitschrift für Soziologie, 44: 330-347. DOI: https:// doi.org/10.1515/zfsoz-2015-0503

Eitzel, MV, Cappadonna, JL, Santos-Lang, C, Duerr, RE, Virapongse, A, West, SE, Conrad, C, Kyba, M, Bowser, A, Cooper, CB, Sforzi, A, Metcalfe, AN, Harris, ES, Thiel, M, Haklay, M, Ponciano, L, Roche, J, Ceccaroni, L, Shilling, FM, Dörler, D, Heigl, F, Kiessling, T, Davis, BY and Jiang, Q. 2017. Citizen Science Terminology Matters: Exploring Key Terms. Citizen Science: Theory and Practice, 2(1): 1-20. DOI: https://doi.org/10.5334/cstp.96

European Commission (EC). 2015. Monitoring the Evolution and Benefits of Responsible Research and Innovation (MoRRI). Synthesis report on existing indicators across RRI dimensions Progress report D3.1. Available at: http://www.technopolis-group.com/wpcontent/uploads/2016/12/2171_D3.1.pdf.

European Commission (EC). 2017. Horizon 2020. Work Programme 2018-2020.

European Commission (EC). 2019. What is Horizon 2020. Available at: https://ec.europa.eu/programmes/horizon2020/what-horizon-2020 (Accessed: 11.2.2019.

Eurostat. 2018. R\&D Expenditure. Available at: http:// ec.europa.eu/eurostat/statistics-explained/index. php?title=R_\%26_D_expenditure\#Further_Eurostat_ information (Accessed 2.5.2018).

Evans, BJ. 2016. Barbarians at the gate: Consumer-driven health data commons and the transformation of citizen science. American Journal of Law \& Medicine, 42:
651-685. DOI: https://doi.org/10.1177/00988588177 00245

Gallo, T and Waitt, D. 2011. Creating a Successful Citizen Science Model to Detect and Report Invasive Species. BioScience, 61(6): 459-465. DOI: https://doi. org/10.1525/bio.2011.61.6.8

Göbel, C, Cappadonna, J, Newman, G, Zhang, J and Vohland, K. 2016. More than Just Networking for Citizen Science: Examining Core Roles of Practitioner Organizations. In: Ceccarone, L and Piera, J (eds.), Analyzing the Role of Citizen Science in Modern Research, 24-49. IGI Global. DOI: https://doi. org/10.4018/978-1-5225-0962-2.ch002

Habermas, J. 1992. Faktizität und Geltung. Beiträge zur Diskurstheorie des Rechts und des demokratischen Rechtsstaats, 1-702. Frankfurt: Suhrkamp.

Haklay, M. 2013. Citizen Science and Volunteered Geographic Information - overview and typology of participation. In: Sui, DZ, Elwood, S and Goodchild, MF (eds.), Crowdsourcing Geographic Knowledge: Volunteered Geographic Information (VGI) in Theory and Practice, 105-122. Berlin: Springer. DOI: https:// doi.org/10.1007/978-94-007-4587-2_7

Harvey, D. 2005. A brief history of neoliberalism. Oxford: Oxford University Press.

Hecker, S, Bonney, R, Haklay, M, Hölker, F, Hofer, H, Goebel, C, Gold, M, Makuch, Z, Ponti, M, Richter, A, Robinson, L, Iglesias, JR, Owen, R, Peltola, T, Sforzi, A, Shirk, J, Vogel, J, Vohland, K, Witt, T and Bonn, A. 2018. Innovation in Citizen Science - Perspectives on Science-Policy Advances. Citizen Science: Theory and Practice, 3(4): 1-14. DOI: https://doi.org/10.5334/ cstp.114

Heigl, F, Dörler, D and Ernst, M. 2018. Austrian Citizen Science Conference 2018. Frontiers Abstract Bool. Frontiers Media SA, 1-101.

Henden, AA. 2011. Amateur Community and "Citizen Science". In: Griffin, REM, Hanisch, RJ and Seaman, $\mathrm{R}$ (eds.), New Horizons in Time-Domain Astronomy. Proceedings IAU Symposium No. 285. DOI: https://doi. org/10.1017/S1743921312000695

Hottenrott, $\mathbf{H}$ and Thorwarth, S. 2011. Industry Funding of University Research and Scientific Productivity. DOI: https://doi.org/10.2139/ssrn.1786418

Irwin, A. 1995. Citizen Science, 1-216. London: Routledge.

Kühn, E, Musche, M, Harpke, A, Feldmann, R, Metzler, B, Wiemers, M, Hirneisen, N and Settele, J. 2014. Tagfalter-Monitoring Deutschland - Anleitung für Transektzähler. Oedippus Band, 27: 1-47.

Kullenberg, C and Kasperowski, D. 2016. What Is Citizen Science? - A Scientometric Meta-Analysis. PLoS ONE, 11(1): e0147152. DOI: https://doi.org/10.1371/ journal.pone.0147152

Lave, R. 2017. Neoliberalism and the Production of Environmental Knowledge. Environment and Society, 8: 19-38.

League of European Research Universities (Leru). 2016. Citizen science at universities: Trends, guidelines and recommendations. 
Marshall, PJ, Lintott, CJ and Fletcher, LN. 2015. Ideas for Citizen Science in Astronomy. Ann. Rev. Astron. Astrophysics, 53: 247-278. DOI: https://doi. org/10.1146/annurev-astro-081913-035959

McCluskey, M. 2017. Public Universities Get an Education in Private Industry. Can academic researchers remain impartial if they are beholden to corporate money? The Atlantic, 3.4.2017. Available at: https:// www.theatlantic.com/education/archive/2017/04/ public-universities-get-an-education-in-private-industry/521379/.

McKinley, DC, Miller-Rushing, AJ, Ballard, HL, Bonney, R, Brown, H, Cook-Patton, SC, Evans, DM, French, RA, Parrish, JK and Phillips, TB. 2017. Citizen science can improve conservation science, natural resource management, and environmental protection. Biological Conservation, 208: 15-28. DOI: https://doi. org/10.1016/j.biocon.2016.05.015

Michelucci, $\mathbf{P}$ and Dickinson, J. 2016. The power of crowds. Science, 351: 33-34. DOI: https://doi. org/10.1126/science.aad6499

Mirowski, P. 2017. Against citizen science. It might style itself as a grassroots movement but citizen science is little more than a cheap land-grab by big business. Available at: https://aeon.co/essays/is-grassroots-citizen-science-a-front-for-big-business.

Moorthy, I, Fritz, S, See, L, Wehn, U, Hemment, D, Pau, JM, Tsertou, A, Vohland, K, Ferri, M, McCallum, I, Domian, D, Hager, G and Perger, C. 2018. WeObserve: An Ecosystem of Citizen Observatories for Environmental Monitoring. Available at: https://meetingorganizer. copernicus.org/EGU2018/EGU2018-14026-1.pdf.

NYU Tandon School of Engineering. 2017. Bored by physical therapy? Focus on citizen science instead.

Oswald, K and Smolarski, R. 2016. Bürger Künste Wissenschaft. Citizen Science in Kultur und Geisteswissenschaften, 1-247. Computus Druck Satz \& Verlag.

Ottinger, G. 2010. Buckets of Resistance: Standards and the Effectiveness of Citizen Science. Science, Technology, \& Human Values, 35(2): 244-270. DOI: https://doi.org/10.1177/0162243909337121

Ottinger, G. 2017. Reconstructing or reproducing? Scientific authority and models of change in two traditions of citizen science. In: Tyfield, D, Lave, R, Randalls, $\mathrm{S}$ and Thorpe, C (eds.), The Routledge Handbook of the Political Economy of Science Routledge International Handbooks, 351-363. London and New York: Taylor \& Francis Group.

Pages, M, Fischer, A, van der Wal, R and Lambin, X. 2019. Empowered communities or "cheap labour"? Engaging volunteers in the rationalised management of invasive alien species in Great Britain. Journal of Environmental Management, 229: 102-111. DOI: https://doi.org/10.1016/j.jenvman.2018.06.053

Pagoulatos, G and Kastritis, P. 2013. Theorizing and Assessing Civil Society: A review of approaches. The Jean Monnet Papers on Political Economy, 2013(3): 1-20.

Palacin-Silva, M, Seffah, A, Heikkinen, K, Porras, J, Pyhälahti, T, Sucksdorff, Y, Anttila, S, Alasalmi, H,
Bruun, E and Junttila, S. 2016. State-of-the Art Study in Citizen Observatories: Technological Trends, Development Challenges and Research Avenues.

Pettibone, L, Vohland, K and Ziegler, D. 2017. Understanding the (inter)disciplinary and institutional diversity of citizen science: A survey of current practice in Germany and Austria. PlosOne, 12(6): e0178778. DOI: https://doi.org/10.1371/journal. pone. 0178778

Quinn, P. 2018. Is the GDPR and Its Right to Data Portability a Major Enabler of Citizen Science? Global Jurist, 18: 20180021. DOI: https://doi.org/10.1515/ gj-2018-0021

Redner, H. 1987. The institutionalization of science: A critical synthesis. Social Epistemology, 1(1): 37-59. DOI: https://doi.org/10.1080/02691728708578412

Riesch, H and Potter, C. 2014. Citizen science as seen by scientists: Methodological, epistemological and ethical dimensions. Public Understanding of Science, 23(1): 107-120. DOI: https://doi. org/10.1177/0963662513497324

Robinson, LD, Cawthray, JL, West, SE, Bonn, A and Ansine, J. 2018. Ten principles of citizen science. In: Hecker, S, Haklay, M, Bowser, A, Makuch, Z, Vogel, J and Bonn, A (eds.), Citizen Science - Innovation in Open Science, Society and Policy, 27-40. London: UCL Press. DOI: https://doi.org/10.2307/j.ctv550cf2.9

Rosol, M. 2011. Community Volunteering as Neoliberal Strategy? Green Space Production in Berlin. Antipode, 44(1): 239-257. DOI: https://doi.org/10.1111/j.14678330.2011.00861.x

See, L. 2019. A Review of Citizen Science and Crowdsourcing in Applications of Pluvial Flooding. Frontiers in Earth Science 7, UNSP 44. DOI: https://doi. org/10.3389/feart.2019.00044

Sforzi, A, Tweddle, J, Vogel, J, Lois, G, Wägele, W, Lakeman-Fraser, P, Makuch, Z and Vohland, K. 2018. Citizen science and the role of natural history museums. In: Hecker, S, Haklay, M, Bowser, A, Makuch, Z, Vogel, J and Bonn, A (eds.), Citizen Science. Innovation in Open Science, Society and Policy, 429-444. London: UCL Press. DOI: https://doi.org/10.2307/j. ctv550cf2.36

Simoniello, C, Jencks, J, Lauro, FM, Loftis, JD, Weslawski, JM, Deja, K, Forrest, DR, Gossetts, S, Jeffries, TC, Jensen, RM, Kobara, S, Nolan, L, Ostrowski, M, Pounds, D, Roseman, G, Basco, O, Gosselin, S, Reed, A, Wills, P and Wyatt, D. 2019. Citizen-Science for the Future: Advisory Case Studies From Around the Globe. Frontiers in Marine Sciences 6, UNSP 225. DOI: https://doi.org/10.3389/ fmars.2019.00225

Stedman Jones, D. 2012. Masters of the Universe Hayek, Friedman, and the Birth of Neoliberal Politics.

Storksdieck, MJLS, Cappadonna, JL, Domroese, M, Göbel, C, Haklay, M, Roetman, P, Sbrocchi, C and Vohland, K. 2016. Associations for citizen science: Regional knowledge; global collaboration. Citizen Science: Theory and Practice, 2(1): 1-10. DOI: https:// doi.org/10.5334/cstp.55 
Suman, AB and Pierce, R. 2018. Challenges for Citizen Science and the EU Open Science Agenda under the GDPR. European Data Protection Law Review, 4: 284-295. DOI: https://doi.org/10.21552/ edpl/2018/3/7

Tiago, P, Gouveia, MJ, Capinha, C, Santos-Reis, M and Pereira, HM. 2017. The influence of motivational factors on the frequency of participation in citizen science activities. Nature Conservation, 61-78. DOI: https:// doi.org/10.3897/natureconservation.18.13429

Turrini, T, Dörler, D, Richter, A, Heigl, F and Bonn, A. 2018. The threefold potential of environmental citizen science - Generating knowledge, creating learning opportunities and enabling civic participation. Biological Conservation, 225: 176-186. DOI: https://doi. org/10.1016/j.biocon.2018.03.024

Tyfeld, D, Lave, R, Randalls, S and Thorpe, C. 2017. Introduction: Beyond crisis in the knowledge economy. In: Tyfield, D, Lave, R, Randalls, S and Thorpe, C (eds.), The Routledge Handbook of the Political Economy of Science Routledge International Handbooks, 1-18. London and New York: Taylor \& Francis Group. DOI: https://doi.org/10.4324/9781315685397-1

Tyfield, D, Lave, R, Randalls, $\mathbf{S}$ and Thorpe, C. (eds.) 2017. The Routledge Handbook of the
Political Economy of Science. London and New York: Taylor \& Francis Group. DOI: https://doi. org/10.4324/9781315685397

Wildschut, D. 2016. The need for citizen science in the transition to a sustainable peer-to-peer-society. Futures, 91: 46-52. DOI: https://doi.org/10.1016/j. futures.2016.11.010

Wilkinson, MD, Dumontier, M, Aalbersberg, IJ, Appleton, G, Axton, M, Baak, A, Blomberg, N, Boiten, J-W, da Silva Santos, LB, Bourne, PE, Bouwman, J, Brookes, AJ, Clark, T, Crosas, M, Dillo, I, Dumon, O, Edmunds, S, Evelo, CT, Finkers, R, Gonzalez-Beltran, A, Gray, AJG, Groth, P, Goble, C, Grethe, JS, Heringa, J, 't Hoen, PAC, Hooft, R, Kuhn, T, Kok, R, Kok, J, Lusher, SJ, Martone, ME, Mons, A, Packer, AL, Persson, B, Rocca-Serra, P, Roos, M, van Schaik, R, Sansone, S-A, Schultes, E, Sengstag, T, Slater, T, Strawn, G, Swertz, MA, Thompson, $M$, van der Lei, J, van Mulligen, E, Velterop, J, Waagmeester, A, Wittenburg, P, Wolstencroft, K, Zhao, J and Mons, B. 2016. Comment: The FAIR Guiding Principles for scientific data management and stewardship. Scientific Data, 3, UNSP 160018. DOI: https://doi.org/10.1038/ sdata.2016.18

How to cite this article: Vohland, K, Weißpflug, M and Pettibone, L. 2019. Citizen Science and the Neoliberal Transformation of Science - an Ambivalent Relationship. Citizen Science: Theory and Practice, 4(1): 25, pp.1-9. DOl: https://doi.org/10.5334/cstp.186 provided the original author and source are credited. See https://creativecommons.org/licenses/by/4.0/. 